\title{
Bioconversion of Cassava Stem to Ethanol Using Aspergillus fumigatus and Saccharomyces cerevisiae
}

\author{
Bo Yu, ${ }^{\mathrm{a}, \mathrm{b}}$ Luqiao Jin, ${ }^{\mathrm{a}}$ Huiling Xia, ${ }^{\mathrm{b}} \mathrm{Yu} \mathrm{Lu},{ }^{\mathrm{b}}$ and Mengyi Dong ${ }^{\mathrm{a}, *}$
}

Cassava stem was bioconverted to ethanol using microorganisms. First, cassava stem was pretreated by in ways, alkaline solution alone (ASA), microwave treatment combined with alkaline solution (MTCAS), and ultrasonic treatment combined with alkaline solution (UTCAS). The compositions of cassava stem pretreated by different methods were analyzed, and the results showed that the cassava stem pretreated by MTCAS was more suitable for saccharification and subsequent ethanol production. The pretreated cassava stem was subjected to simultaneous saccharification and ethanol production using Aspergillus fumigatus and Saccharomyces cerevisiae. Response surface methodology was used to optimize various process parameters including fermentation temperature, initial $\mathrm{pH}$, fermentation time, rotational speed and substrate concentration. A bioconversion yield of $70 \mathrm{mg} / \mathrm{g}$ was obtained at the optimum conditions of fermentation, viz, temperature $35^{\circ} \mathrm{C}$, initial $\mathrm{pH} \mathrm{5.6}$, fermentation time $132 \mathrm{~h}$, rotational speed $155 \mathrm{rpm}$, and substrate concentration $4.6 \mathrm{wt} \%$. An experiment under optimum conditions confirmed the model predictions. The results suggest that pretreatment with MTCAS and simultaneous fermentation with $A$. fumigatus and $S$. cerevisiae would be a good choice for the bioconversion of lignocellulosic biomass to bioethanol. Considering the cost advantage, using microbial fermentation instead of pure enzyme hydrolysis is more advantageous in $2^{\text {nd }}$ generation bioethanol production.

Keywords: Bioconversion; Cassava stem; Pretreatment; Respond surface methodology

Contact information: a: School of Resources Environmental \& Chemical Engineering, Key Laboratory of Poyang Lake Environment and Bio-Resources Utilization, Ministry of Education China, Nanchang University, Nanchang 330031, China; b: Sino-German Joint Research Institute, Nanchang University, Nanchang 330047, China; *Corresponding author: DongMYncu@163.com

\section{INTRODUCTION}

Today, environmental pollution, the greenhouse effect, and global climate change are urgent and sensitive issues (Septia et al. 2018; Cinthia et al. 2019; Intaramas et al. 2018). It is well known that the use of a renewable resource to replace traditional fossil fuels would be a good alternative to solve these problems (Jin-Ho and Volker 2017; Germec and Turhan 2018; Niethammer et al. 2018; Zhou et al. 2018). In particular, the bioconversion of lignocellulosic biomass to bioenergy, such as biofuel and bioethanol, is considered a potential way to substitute traditional energy (Pattiya et al. 2012; Shen et al. 2017; Yang et al. 2018).

For this reason, bioethanol production from lignocellulosic biomass, usually agricultural wastes, is gaining increasing research interest (André et al. 2018; Singh et al. 2018). In general, there are three steps involved in the bioconversion of lignocellulosic biomass to bioethanol: pretreatment, saccharification, and ethanol production.

Pretreatment with alkali is a traditional method to remove the lignin from lignocellulosic biomass (Zhu et al. 2005). However, it is inefficient due to its high loss of 
cellulose and hemicellulose as well as being time consuming. Further improvements are required, and many researchers are doing great work in this field. The purpose of saccharification is to convert cellulose and hemicellulose into fermentable sugars. Cellulase from microorganisms is often used in the saccharification process. However, the production costs of bioethanol will be raised greatly due to the use of an enzyme. It would be an effective alternative method to use microorganisms that can produce cellulase and hemicellulase instead of a commercial enzyme. Ethanol production is the last step in which saccharification products are fermented and fermentable sugar is converted into ethanol by yeast.

Cassava is a starchy crop belonging to the Euphorbiaceae family (Martin et al. 2017). It is cultivated in many countries across Africa, Asia, and South America (Veiga et al. 2016). According to the Food and Agriculture Organization's (FAO) estimates, 233 million tons of cassava was produced worldwide in 2008, and the amount has been growing for nearly a decade (Pattiya 2011; Pattiya et al. 2012). As the main agricultural waste product of the cassava industry, cassava stem is a good source of lignocellulosic biomass that can be converted into bioethanol (Tanaka et al. 2019). Various researchers have reported the process and conditions of bioethanol production from cassava stem. Kouten et al. (2016) reported that pretreated cassava stems and peelings via thermohydrolysis and fermentation with cellulase can obtain a satisfactory saccharification yield (Kouteu et al. 2016). Kamalini et al. (2018) used a response surface methodology (RSM) with a BoxBehnken design (BBD) that was employed to investigate the optimum conditions for a microwave-assisted alkaline pretreatment of cassava stem (Kamalini et al. 2018). However, most of these studies focused on the process of saccharification of cassava stem, and few studies applied the last step of bioconversion, which is ethanol production.

To bioconvert the cassava stem into ethanol in an efficient and cost-effective way, the pretreatment, saccharification, and ethanol production of cassava stem were studied in this work. Three methods of pretreatment were compared, these included pretreatment by alkaline alone (AA), microwave treatment combined with alkaline solution (MTCAS), and ultrasonic treatment combined with alkaline solution (UTCAS). Aspergillus fumigatus and Saccharomyces cerevisiae were used for the saccharification and ethanol production in one fermentation process. Additionally, the level of fermentation factors were optimized using RSM. An outline of the work is shown in Fig. 1.

\section{EXPERIMENTAL}

\section{Raw Material}

Cassava stem was obtained from local agricultural fields in Dongxiang, Jiangxi province, China. The cassava stem were cut into $2-\mathrm{cm}$ length pieces and baker-dried to a 5 wt $\%$ moisture content at $105{ }^{\circ} \mathrm{C}$. After naturally cooling to room temperature, they were milled to pass through a 40 -mesh screen. The obtained powders were conditioned in sealed plastic bags and stored at ambient temperature $\left(25 \pm 3{ }^{\circ} \mathrm{C}\right)$ until further use.

\section{Fermentation strain}

The fungus Aspergillus fumigatus (CICC 2434) that can produce cellulase and hemicellulase was used as the fermentation strain for saccharification. The yeast Saccharomyces cerevisiae (CICC 1023) that can convert fermentable sugar into ethanol was used as the fermentation strain for ethanol production. They were purchased from the 
China Center of Industrial Culture Collection (CICC; Beijing, China) and were plated in malt-agar medium ( $5^{\circ}$ Bé, degree Baumé). The A. fumigatus was incubated at $45^{\circ} \mathrm{C}$, and the $S$. cerevisiae was incubated at $30^{\circ} \mathrm{C}$ for colony formation. A. fumigatus suspensions were prepared using sterile water. The spore count was adjusted to $2 \times 10^{6}$ spores $/ \mathrm{mL}$. $S$. cerevisiae inoculi were prepared using malt juice culture. The number of viable spores was adjusted to $5 \times 10^{8}$ Colony-forming Units $(\mathrm{CFU}) / \mathrm{mL}$.

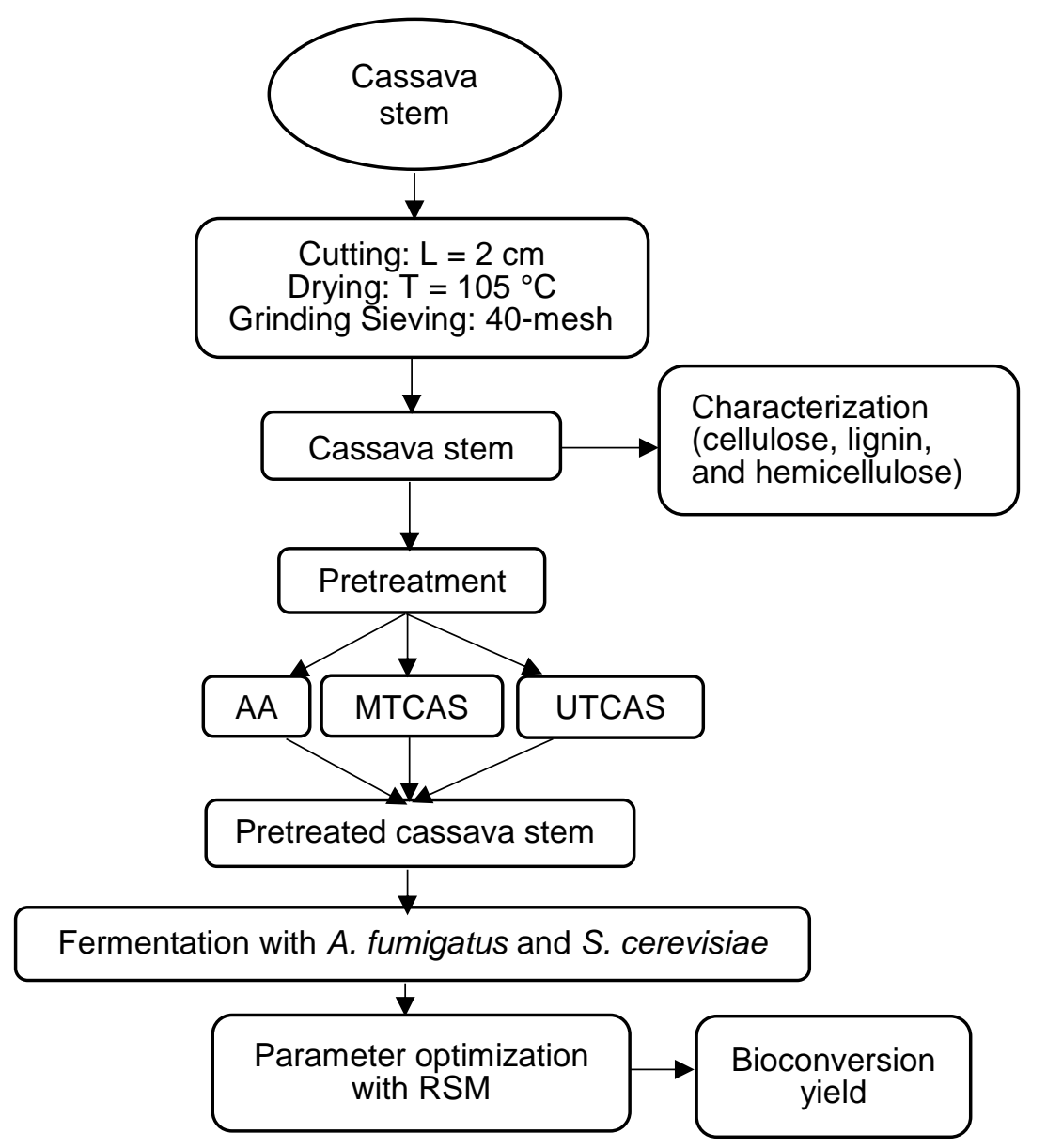

Fig. 1. The outline of experimental process

\section{Pretreatment}

Pretreatment by alkaline solution alone (ASA)

Samples $(20 \mathrm{~g})$ of cassava stem powder were suspended in $200 \mathrm{~mL}$ of $\mathrm{NaOH}$ aqueous solution and boiled in a 500-mL beaker (treatment temperature $100{ }^{\circ} \mathrm{C}$ ) for different times, as designated in Table 1. The residues were collected and extensively washed with tap water until neutral $\mathrm{pH}$. Then, the material was dried and ground into a fine powder.

Pretreatment by microwave treatment combined with alkaline solution (MTCAS)

A total of $20 \mathrm{~g}$ of cassava stem powder were suspended in $200 \mathrm{~mL}$ of $\mathrm{NaOH}$ aqueous solution in the round bottom flask positioned at the center of a microwave reaction station (SINEO MAS-II Plus; Shanghai Xinyi Microwave Chemical Technology Co., Ltd., Shanghai, China) for microwave treatment (treatment temperature $100{ }^{\circ} \mathrm{C}$ ), as designated 
in Table 1. The residues were collected and extensively washed with tap water until neutral $\mathrm{pH}$. The residues were collected and then treated as mentioned above.

Pretreatment by ultrasonic treatment combined with alkaline solution (UTCAS)

A total of $20 \mathrm{~g}$ of cassava stem powder were suspended in $200 \mathrm{~mL}$ of $\mathrm{NaOH}$ aqueous solution in a 500-mL beaker, and the beaker was positioned into an ultrasonic extractor (Scientz EXC933; Ningbo Xinzhi Technology Co., Ltd., Ningbo, China) for ultrasonic treatment (ultrasonic frequency $60 \mathrm{KHz}$, treatment temperature $100{ }^{\circ} \mathrm{C}$ ), as designated in Table 1 . The residues were collected and then treated as mentioned above.

Table 1. Process Parameters and Experimental Design of Pretreatment

\begin{tabular}{|c|c|c|c|c|c|c|c|c|}
\hline \multicolumn{9}{|c|}{ Pretreatment Method } \\
\hline \multicolumn{3}{|c|}{ AA } & \multicolumn{3}{|c|}{ MTCAS } & \multicolumn{3}{|c|}{ UTCAS } \\
\hline Run & $\begin{array}{c}\mathrm{NaOH} \\
\text { (wt\%) }\end{array}$ & $\begin{array}{c}\text { Time } \\
\text { (min) }\end{array}$ & Run & $\begin{array}{c}\mathrm{NaOH} \\
\text { (wt\%) }\end{array}$ & $\begin{array}{l}\text { Time } \\
\text { (min) }\end{array}$ & Run & $\begin{array}{c}\mathrm{NaOH} \\
(\mathrm{wt} \%)\end{array}$ & $\begin{array}{l}\text { Time } \\
\text { (min) }\end{array}$ \\
\hline 1 & 1 & 20 & 10 & 1 & 10 & 19 & 1 & 10 \\
\hline 2 & 1 & 30 & 11 & 1 & 20 & 20 & 1 & 20 \\
\hline 3 & 1 & 40 & 12 & 1 & 30 & 21 & 1 & 30 \\
\hline 4 & 2 & 20 & 13 & 2 & 10 & 22 & 2 & 10 \\
\hline 5 & 2 & 30 & 14 & 2 & 20 & 23 & 2 & 20 \\
\hline 6 & 2 & 40 & 15 & 2 & 30 & 24 & 2 & 30 \\
\hline 7 & 3 & 20 & 16 & 3 & 10 & 25 & 3 & 10 \\
\hline 8 & 3 & 30 & 17 & 3 & 20 & 26 & 3 & 20 \\
\hline 9 & 3 & 40 & 18 & 3 & 30 & 27 & 3 & 30 \\
\hline
\end{tabular}

\section{Bioconversion of Cassava Stem to Ethanol}

The bioconversion of cassava stem was completed in a 500-mL conical flask containing pretreated cassava stem. Pretreated cassava stem was sterilized at $121{ }^{\circ} \mathrm{C}$ for 30 min and cooled. Aspergillus fumigatus and Saccharomyces cerevisiae were inoculated for saccharification and ethanol production, respectively, and incubated in a constant temperature incubator shaker (ZQZY-75AN; Shanghai Zhichu Instrument Co., Ltd. Shanghai, China) for bioconversion. After the bioconversion, the fermentation broth was filtrated to remove the biomass. The bioethanol produced was determined using the potassium dichromate method (William and Reese 1950). The various factors that influence the bioconversion yield, including temperature, initial $\mathrm{pH}$, time, rotational speed, and substrate concentration, were studied using RSM.

The bioconversion yield $Y(\mathrm{mg} / \mathrm{g})$ was calculated using the following Eq. 1,

$$
Y=m / n
$$

where $m$ is the ethanol formed (mg) and $n$ is the pretreated cassava stem $(\mathrm{g})$.

\section{Methods}

Response surface methodology

Response surface methodology was used to study the influence of various process parameters, including fermentation temperature (A), initial $\mathrm{pH}(\mathrm{B})$, fermentation time (C), rotational speed (D), and substrate concentration (E) on the bioconversion yield from cassava stem.

A Box-Behnken design with 46 experiments (40 axial and 6 central points) was elaborated to study the effect of independent variables on the responses (bioconversion 
yield) and interaction of factors. The ranges of selected process parameters are shown in Table 2. The choices of factors, as well as their levels, were determined according to the authors' preliminary research.

Table 2. Minimum and Maximum Values of Various Factors Selected for Optimization of Bioconversion Yield from Cassava Stem

\begin{tabular}{|c|c|c|c|c|}
\hline \multirow{2}{*}{ Variable Codes } & Variables & \multicolumn{3}{|c|}{ Level } \\
\cline { 3 - 5 } & Fermentation temperature $\left({ }^{\circ} \mathrm{C}\right)$ & 25 & 30 & 35 \\
\hline A & Initial $\mathrm{pH}$ & 4 & 5 & 6 \\
\hline B & Fermentation time $(\mathrm{h})$ & 72 & 108 & 144 \\
\hline C & Rotational speed (rpm) & 120 & 150 & 180 \\
\hline D & Substrate concentration $(\mathrm{wt} \%)$ & 3 & 4 & 5 \\
\hline E & & & & \\
\hline
\end{tabular}

\section{Analytical methods}

The moisture was measured as the weight loss of $1 \mathrm{~g}$ cassava stem dried at $105{ }^{\circ} \mathrm{C}$ for $24 \mathrm{~h}$. The cellulose content was determined via the $\mathrm{HNO}_{3}-$ ethanol method. The lignin content was assayed using the $72 \mathrm{wt} \% \mathrm{H}_{2} \mathrm{SO}_{4}$ method. The hemicellulose content was analysed according to the two-brominating method (Liu 2004; Zhu et al. 2005).

\section{Statistical analysis}

The Student's t-test permitted verification of the statistical significance of the regression coefficients. The Fisher's test for analysis of variance (ANOVA) was performed on the experimental data to evaluate the statistical significance of the model. Design Expert 11.0 software (StatEase, Inc., Minneapolis, MN, USA) was employed to determine and evaluate the coefficients of the acquired full regression model equation and their statistical significance.

\section{RESULTS AND DISCUSSION}

The chemical compositions of cassava stems pretreated using different methods are presented in Table 3. The proportions of cellulose, hemicellulose, and lignin of cassava stems without pretreatment (Run 0) were $28.8 \mathrm{wt} \%, 19.2 \mathrm{wt} \%$, and $10.2 \mathrm{wt} \%$, respectively.

The Tukey test was used for the statistical analysis for the significant difference of the data set for each run. There is a significant difference between the mean values followed by different letters in the column, and the significance level is $5 \%$.

\section{Pretreatment}

To facilitate the later saccharification step and obtain as high as possible fermentable sugars yield, the lignocellulose needs to be pretreated to remove the lignin and increase the cellulose and hemicellulose content. 
Table 3. Results of Pretreatment Experiments of Cassava Stem

\begin{tabular}{|c|c|c|c|c|c|c|c|}
\hline Run & $\begin{array}{c}\text { Cellulose } \\
(w+\%)\end{array}$ & $\begin{array}{c}\text { Hemicellulose } \\
(w t \%)\end{array}$ & Lignin (wt\%) & Run & $\begin{array}{c}\text { Cellulose } \\
(\text { wt\% })\end{array}$ & $\begin{array}{c}\text { Hemicellulose } \\
(w+\%)\end{array}$ & Lignin (wt\%) \\
\hline 0 & $28.8 \pm 0.2^{\mathrm{a}}$ & $19.2 \pm 0.4^{\mathrm{a}}$ & $10.2 \pm 0.7^{\mathrm{d}}$ & 14 & $48.1 \pm 0.4^{\mathrm{d}}$ & $22.5 \pm 0.7^{\mathrm{b}}$ & $4.80 \pm 0.6^{\mathrm{ab}}$ \\
\hline 1 & $33.6 \pm 0.4^{\mathrm{b}}$ & $20.1 \pm 0.4^{\mathrm{a}}$ & $7.9 \pm 0.9^{\mathrm{d}}$ & 15 & $50.1 \pm 0.5^{\mathrm{d}}$ & $23.1 \pm 0.4^{\mathrm{c}}$ & $4.0 \pm 0.2^{\mathrm{a}}$ \\
\hline 2 & $42.5 \pm 0.6^{\mathrm{c}}$ & $21.0 \pm 0.5^{\mathrm{ab}}$ & $6.2 \pm 1.3^{\mathrm{c}}$ & 16 & $48.0 \pm 0.3^{\mathrm{d}}$ & $22.2 \pm 0.4^{\mathrm{b}}$ & $5.0 \pm 0.2^{\mathrm{ab}}$ \\
\hline 3 & $43.9 \pm 0.2^{\mathrm{c}}$ & $21.4 \pm 0.3^{\mathrm{ab}}$ & $5.7 \pm 0.8^{\mathrm{bc}}$ & 17 & $50.7 \pm 0.6^{\mathrm{d}}$ & $23.4 \pm 0.4^{\mathrm{c}}$ & $4.20 \pm 0.3^{\mathrm{a}}$ \\
\hline 4 & $43.8 \pm 0.3^{\mathrm{c}}$ & $21.1 \pm 0.2^{\mathrm{ab}}$ & $5.9 \pm 0.6^{\mathrm{bc}}$ & 18 & $52.1 \pm 0.5^{\mathrm{d}}$ & $24.0 \pm 0.6^{\mathrm{d}}$ & $3.60 \pm 0.4^{\mathrm{a}}$ \\
\hline 5 & $44.2 \pm 0.8^{\mathrm{c}}$ & $21.4 \pm 1.1^{\mathrm{ab}}$ & $5.0 \pm 0.8^{\mathrm{ab}}$ & 19 & $36.4 \pm 0.3^{\mathrm{bc}}$ & $19.6 \pm 0.4^{\mathrm{a}}$ & $8.2 \pm 0.6^{\mathrm{d}}$ \\
\hline 6 & $45.8 \pm 0.3^{\mathrm{c}}$ & $21.8 \pm 0.4^{\mathrm{b}}$ & $4.70 \pm 0.2^{\mathrm{a}}$ & 20 & $40.9 \pm 0.5^{\mathrm{bc}}$ & $20.8 \pm 0.3^{\mathrm{a}}$ & $7.20 \pm 0.9^{\mathrm{c}}$ \\
\hline 7 & $47.0 \pm 0.6^{\mathrm{cd}}$ & $22.1 \pm 0.5^{\mathrm{b}}$ & $4.50 \pm 0.1^{\mathrm{a}}$ & 21 & $44.6 \pm 0.4^{\mathrm{c}}$ & $21.7 \pm 0.3^{\mathrm{b}}$ & $5.80 \pm 0.4^{\mathrm{b}}$ \\
\hline 8 & $48.2 \pm 0.5^{\mathrm{d}}$ & $22.4 \pm 1.3^{\mathrm{b}}$ & $4.4 \pm 0.8^{\mathrm{a}}$ & 22 & $42.1 \pm 0.4^{\mathrm{c}}$ & $20.3 \pm 0.1^{\mathrm{a}}$ & $7.0 \pm 0.4^{\mathrm{cd}}$ \\
\hline 9 & $48.6 \pm 0.3^{\mathrm{d}}$ & $22.9 \pm 0.5^{\mathrm{bc}}$ & $4.0 \pm 0.2^{\mathrm{a}}$ & 23 & $44.9 \pm 0.7^{\mathrm{c}}$ & $22.0 \pm 0.4^{\mathrm{b}}$ & $5.4 \pm 0.3^{\mathrm{b}}$ \\
\hline 10 & $40.5 \pm 0.2^{\mathrm{bc}}$ & $20.5 \pm 0.5^{\mathrm{a}}$ & $7.0 \pm 0.7^{\mathrm{cd}}$ & 24 & $46.2 \pm 0.6^{\mathrm{c}}$ & $22.7 \pm 0.6^{\mathrm{bc}}$ & $4.8 \pm 0.4^{\mathrm{ab}}$ \\
\hline 11 & $47.5 \pm 0.5^{\mathrm{c}}$ & $21.4 \pm 0.3^{\mathrm{ab}}$ & $5.70 \pm 0.8^{\mathrm{bc}}$ & 25 & $46.0 \pm 0.6^{\mathrm{c}}$ & $21.1 \pm 0.5^{\mathrm{ab}}$ & $5.50 \pm 0.1^{\mathrm{b}}$ \\
\hline 12 & $48.7 \pm 0.6^{\mathrm{d}}$ & $22.1 \pm 0.4^{\mathrm{b}}$ & $4.5 \pm 0.4^{\mathrm{a}}$ & 26 & $47.8 \pm 0.3^{\mathrm{c}}$ & $22.8 \pm 0.8^{\mathrm{c}}$ & $4.4 \pm 0.2^{\mathrm{a}}$ \\
\hline 13 & $43.2 \pm 0.6^{\mathrm{c}}$ & $21.4 \pm 0.1^{\mathrm{ab}}$ & $6.2 \pm 0.7^{\mathrm{bc}}$ & 27 & $49.5 \pm 0.3^{\mathrm{d}}$ & $23.7 \pm 0.5^{\mathrm{c}}$ & $4.0 \pm 0.2^{\mathrm{a}}$ \\
\hline
\end{tabular}

From Table 3, it can be found that within the same pretreatment method and at the same $\mathrm{NaOH}$ concentration, the content of cellulose and hemicellulose increased and the lignin decreased with increased treatment time. Furthermore, within the same pretreatment method with the same treatment time, the content of cellulose and hemicellulose increased and the lignin decreased with increased $\mathrm{NaOH}$ concentration.

When compared with different pretreatment methods, it was found that when pretreated with the same $\mathrm{NaOH}$ concentration and treatment time (20 or $30 \mathrm{~min}$ ), MTCAS exhibited the highest cellulose and hemicellulose content and the lowest lignin content. The results of experiment run 15, run 17, and run 18 were more suitable for the request of saccharification. The pretreatment process of run 18 was used in subsequent experiments of bioconversion. Thus, cassava stem were pretreated in $3 \% \mathrm{NaOH}$ solution at $100{ }^{\circ} \mathrm{C}$ for $30 \mathrm{~min}$ in the microwave reaction station. Under these conditions, the pretreated cassava stem for bioconversion containing $52.1 \mathrm{wt} \%$ cellulose, $24 \mathrm{wt} \%$ hemicellulose, and $3.6 \mathrm{wt} \%$ lignin can be obtained.

\section{RSM Analysis}

In the present work, the relationship between the bioconversion yield and five process variables was developed using RSM. The BBD was used to optimize various parameters affecting the bioconversion yield of cassava stem. The experimental design, experimental, and predicted values of bioconversion yield are shown in Table 4. Variance analyses (ANOVA) are shown in Table 5. 
Table 4. Box-Behnken of RSM in Actual Value for Optimization of Bioconversion Yield from Cassava Stem

\begin{tabular}{|c|c|c|c|c|c|c|c|c|c|c|c|c|c|c|c|}
\hline \multirow{2}{*}{ Exp. Order } & \multicolumn{5}{|c|}{ Process Parameters } & \multirow{2}{*}{$Y_{\mathrm{A}}$} & \multirow{2}{*}{$Y_{P}$} & \multirow{2}{*}{$\begin{array}{l}\text { Exp. } \\
\text { Order }\end{array}$} & \multicolumn{5}{|c|}{ Process Parameters } & \multirow{2}{*}{$Y_{\mathrm{A}}$} & \multirow{2}{*}{$Y_{P}$} \\
\hline & A & $\mathrm{B}$ & $\mathrm{C}$ & $\mathrm{D}$ & $E$ & & & & A & $\mathrm{B}$ & $\mathrm{C}$ & $\mathrm{D}$ & $E$ & & \\
\hline 1 & 25 & 4 & 108 & 150 & 4 & 11.55 & 11.97 & 24 & 30 & 6 & 144 & 150 & 4 & 37.18 & 39.26 \\
\hline 2 & 35 & 4 & 108 & 150 & 4 & 6.38 & 5.73 & 25 & 25 & 5 & 108 & 120 & 4 & 11.88 & 14.79 \\
\hline 3 & 25 & 6 & 108 & 150 & 4 & 18.15 & 17.21 & 26 & 35 & 5 & 108 & 120 & 4 & 11.33 & 11.58 \\
\hline 4 & 35 & 6 & 108 & 150 & 4 & 40.26 & 38.25 & 27 & 25 & 5 & 108 & 180 & 4 & 16.17 & 16.51 \\
\hline 5 & 30 & 5 & 72 & 120 & 4 & 3.85 & 1.01 & 28 & 35 & 5 & 108 & 180 & 4 & 36.85 & 34.52 \\
\hline 6 & 30 & 5 & 144 & 120 & 4 & 13.31 & 12.12 & 29 & 30 & 5 & 72 & 150 & 3 & 5.39 & 5.19 \\
\hline 7 & 30 & 5 & 72 & 180 & 4 & 5.17 & 4.27 & 30 & 30 & 5 & 144 & 150 & 3 & 5.39 & 0.46 \\
\hline 8 & 30 & 5 & 144 & 180 & 4 & 32.78 & 33.53 & 31 & 30 & 5 & 72 & 150 & 5 & 13.2 & 18.70 \\
\hline 9 & 30 & 4 & 108 & 150 & 3 & 5.94 & 7.13 & 32 & 30 & 5 & 144 & 150 & 5 & 63.03 & 63.80 \\
\hline 10 & 30 & 6 & 108 & 150 & 3 & 3.85 & 2.58 & 33 & 25 & 5 & 108 & 150 & 3 & 4.95 & 4.92 \\
\hline 11 & 30 & 4 & 108 & 150 & 5 & 20.9 & 22.12 & 34 & 35 & 5 & 108 & 150 & 3 & 10.23 & 13.97 \\
\hline 12 & 30 & 6 & 108 & 150 & 5 & 65.67 & 64.43 & 35 & 25 & 5 & 108 & 150 & 5 & 49.17 & 44.99 \\
\hline 13 & 25 & 5 & 72 & 150 & 4 & 7.15 & 7.28 & 36 & 35 & 5 & 108 & 150 & 5 & 51.15 & 50.74 \\
\hline 14 & 35 & 5 & 72 & 150 & 4 & 4.95 & 5.06 & 37 & 30 & 4 & 108 & 120 & 4 & 3.41 & 3.17 \\
\hline 15 & 25 & 5 & 144 & 150 & 4 & 16.5 & 17.84 & 38 & 30 & 6 & 108 & 120 & 4 & 12.65 & 14.02 \\
\hline 16 & 35 & 5 & 144 & 150 & 4 & 33.55 & 34.87 & 39 & 30 & 4 & 108 & 180 & 4 & 7.26 & 7.47 \\
\hline 17 & 30 & 5 & 108 & 120 & 3 & 3.96 & 4.62 & 40 & 30 & 6 & 108 & 180 & 4 & 32.56 & 34.38 \\
\hline 18 & 30 & 5 & 108 & 180 & 3 & 6.38 & 7.22 & 41 & 30 & 5 & 108 & 150 & 4 & 36.3 & 36.78 \\
\hline 19 & 30 & 5 & 108 & 120 & 5 & 34.21 & 33.30 & 42 & 30 & 5 & 108 & 150 & 4 & 34.65 & 36.78 \\
\hline 20 & 30 & 5 & 108 & 180 & 5 & 56.1 & 55.37 & 43 & 30 & 5 & 108 & 150 & 4 & 37.95 & 36.78 \\
\hline 21 & 30 & 4 & 72 & 150 & 4 & 2.2 & 0.19 & 44 & 30 & 5 & 108 & 150 & 4 & 36.41 & 36.78 \\
\hline 22 & 30 & 6 & 72 & 150 & 4 & 2.75 & 2.96 & 45 & 30 & 5 & 108 & 150 & 4 & 37.51 & 36.78 \\
\hline 23 & 30 & 4 & 144 & 150 & 4 & 4.4 & 4.26 & 46 & 30 & 5 & 108 & 150 & 4 & 37.84 & 36.78 \\
\hline
\end{tabular}

A: fermentation temperature $\left({ }^{\circ} \mathrm{C}\right) ; \mathrm{B}$ : Initial pH; C: Reaction time (h); D: Rotational speed (rpm); $\mathrm{E}$ : Substrate concentration (wt\%); $Y_{\mathrm{A}}$ : Actual value of bioconversion yield $(\mathrm{mg} / \mathrm{g}) ; Y_{\mathrm{P}}$ : Predicted value of bioconversion yield $(\mathrm{mg} / \mathrm{g})$

\section{Modelling}

The second-degree polynomial model for the bioconversion yield is given as Eq. 2 (In terms of coded factors).

$Y_{\text {Bioconversion yield }}=36.78+3.70 \times A+9.44 \times B+10.09 \times C+6.17 \times D+19.21 \times E-$ $6.95 \times A^{2}-11.54 \times B^{2}-13.57 \times C^{2}-10.48 \times D^{2}-1.17 \times E^{2}+6.82 \times A \times B+4.81 \times A \times C$ $+5.31 \times A \times D-0.83 \times A \times E+8.06 \times B \times C+4.02 \times B \times D+11.72 \times B \times E+4.54 \times C \times D$ $+12.46 \times C \times \mathrm{E}+4.87 \times D \times E$

where $A, B, C, D$, and $E$ are fermentation temperature $\left({ }^{\circ} \mathrm{C}\right)$, initial $\mathrm{pH}$, fermentation time (h), rotational speed (rpm), and substrate concentration (wt \%), respectively.

The Model F-value of 120.76 implies that the model is significant. There was only a $0.01 \%$ chance that a "Model F-Value" this large could occur due to noise. Values of "Prob. > F" less than 0.0500 indicate the model terms are significant. In this case, A, B, C, $\mathrm{D}, \mathrm{E}, \mathrm{A}^{2}, \mathrm{~B}^{2}, \mathrm{C}^{2}, \mathrm{D}^{2}, \mathrm{AB}, \mathrm{AC}, \mathrm{AD}, \mathrm{BC}, \mathrm{BD}, \mathrm{BE}, \mathrm{CD}, \mathrm{CE}$, and $\mathrm{DE}$ are significant model terms. The substrate concentration $(\mathrm{E})$ was the most significant variable for the production 
of ethanol from cassava stem due to its higher $\mathrm{F}$ value (977.87) and lower p-value (< 0.0001).

Values greater than 0.1000 indicate that the model terms are not significant. In this case, $\mathrm{E}^{2}$ and $\mathrm{AE}$ were insignificant model terms. The lack of fit F-value of 4.51 implies that there is a $5.11 \%$ chance that a lack of fit F-value this large could occur due to noise. Lack of fit is bad because the model needs to fit. The "Pred R-Squared" ( $\mathrm{R}^{2}$ Pred) of 0.9604 is in reasonable agreement with the "Adj R-Squared" $\left(\mathrm{R}^{2}\right.$ Adj $)$ of 0.9816. The "Adeq Precision" measures the signal to noise ratio. A ratio greater than 4 is desirable. The authors' ratio of 38.690 indicates an adequate signal. The authors' model can be used to navigate the design space.

Effect of process variables on the bioconversion yield

From this regression model, all five variables showed positive effects on the bioconversion yield. This indicated that increasing the level of these variables at the range of experimental design will improve the bioconversion yield. The substrate concentration (E) was the most significant variable for the bioconversion yield from cassava stem due to its higher F value (977.87) and lower p-value $(<0.0001)$.

Table 5. ANOVA for Response Surface Quadratic Model of Bioconversion Yield

\begin{tabular}{|c|c|c|c|c|c|}
\hline Source & Sum of Squares & DF & Mean Square & F Value & Prob. $>$ F \\
\hline Model & 14581.63 & 20 & 729.08 & 120.76 & $<0.0001$ \\
\hline$A$ & 218.89 & 1 & 218.89 & 36.26 & $<0.0001$ \\
\hline B & 1425.63 & 1 & 1425.63 & 236.14 & $<0.0001$ \\
\hline C & 1629.74 & 1 & 1629.74 & 269.95 & $<0.0001$ \\
\hline D & 608.49 & 1 & 608.49 & 100.79 & $<0.0001$ \\
\hline E & 5903.62 & 1 & 5903.62 & 977.87 & $<0.0001$ \\
\hline$A^{2}$ & 421.35 & 1 & 421.35 & 69.79 & $<0.0001$ \\
\hline$B^{2}$ & 1162.39 & 1 & 1162.39 & 192.54 & $<0.0001$ \\
\hline $\mathrm{C}^{2}$ & 1606.29 & 1 & 1606.29 & 266.07 & $<0.0001$ \\
\hline $\mathrm{D}^{2}$ & 958.06 & 1 & 958.06 & 158.69 & $<0.0001$ \\
\hline $\mathrm{E}^{2}$ & 12.01 & 1 & 12.01 & 1.99 & 0.1706 \\
\hline $\mathrm{AB}$ & 186.05 & 1 & 186.05 & 30.82 & $<0.0001$ \\
\hline $\mathrm{AC}$ & 92.64 & 1 & 92.64 & 15.34 & 0.0006 \\
\hline $\mathrm{AD}$ & 112.68 & 1 & 112.68 & 18.66 & 0.0002 \\
\hline $\mathrm{AE}$ & 2.72 & 1 & 2.72 & 0.45 & 0.5080 \\
\hline $\mathrm{BC}$ & 259.69 & 1 & 259.69 & 43.02 & $<0.0001$ \\
\hline $\mathrm{BD}$ & 64.48 & 1 & 64.48 & 10.68 & 0.0031 \\
\hline $\mathrm{BE}$ & 548.96 & 1 & 548.96 & 90.93 & $<0.0001$ \\
\hline $\mathrm{CD}$ & 82.36 & 1 & 82.36 & 13.64 & 0.0011 \\
\hline $\mathrm{CE}$ & 620.76 & 1 & 620.76 & 102.82 & $<0.0001$ \\
\hline $\mathrm{DE}$ & 94.77 & 1 & 94.77 & 15.70 & 0.0005 \\
\hline Lack of Fit & 143.00 & 20 & 7.15 & 4.51 & 0.0511 \\
\hline $\mathrm{R}^{2}$ & 0.9898 & & $\mathrm{R}^{2}$ Adj & 0.9816 & \\
\hline $\mathrm{R}^{2}$ Pred & 0.9604 & & Adeq. Precision & 38.69 & \\
\hline & & & & & \\
\hline
\end{tabular}


From Table 5, it is observed that the interaction effect of fermentation time (C) and substrate concentration (E) showed a highly significant effect on yield than other interactions because it has a high F-value of 620.76 and low p-value of $(<0.0001)$. This result indicated that increasing the variables $(\mathrm{C}$ and $\mathrm{E})$ will result in increased yield. Moreover, the interaction between fermentation temperature (A) and substrate concentration (E) was not significant, which may have been attributable to the selected range of fermentation temperature $\left(25\right.$ to $\left.35^{\circ} \mathrm{C}\right)$ that resulted in either decreased enzyme activity produced by the fermentation strain or limited growth of the fermentation strain.

According to the BBD, the experimental bioconversion yield of $71.4 \mathrm{mg} / \mathrm{g}$ was obtained at optimum conditions of fermentation temperature $35{ }^{\circ} \mathrm{C}$, initial $\mathrm{pH} 5.6$, fermentation time $132 \mathrm{~h}$, rotational speed $155 \mathrm{rpm}$, and substrate concentration $4.6 \mathrm{wt} \%$. This result was validated at its optimal conditions in triplicates and the experimental results match well with the predicted values from the model equation.

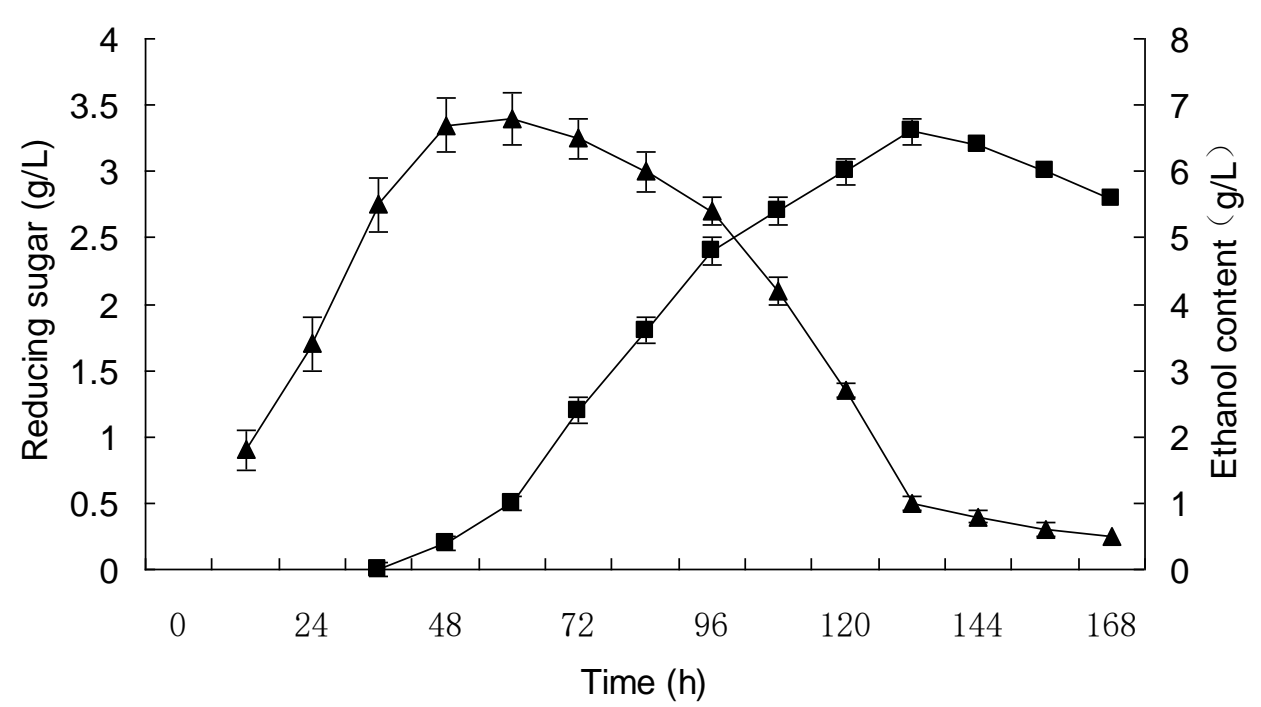

Fig. 2 The fermentation kinetic plot of production of reducing sugar and ethanol. Results are the average of three replicates, and bars indicate standard error of three replicates. ( $\boldsymbol{\Delta}$ reducing sugar ethanol content)

A. fumigatus was found to produce cellulase and hemicellulase early. However, there are few studies on the possible industrial application of enzymes from this fungus. It was of interest in the current study to examine the feasibility of using A. fumigatus cellulase and xylanase to convert lignocellulosic biomass into fermentable sugars.

Cassava stem was selected as a substrate for bioconversion because of its local and abundant availability. Lignocellulosic biomass cannot be bioconverted by enzymes or microorganisms in a high yield without a pretreatment procedure because the lignin in the plant cell wall is a barrier to enzyme action (Kouteu Nanssou et al. 2016). In the present study, cassava stem was pretreated via microwave combined with alkaline prior to fermentation. This treatment was effective in fractionating the hemicellulose and lignin components (Zhu et al. 2005).

During bioconversion of cassava stem, fermentation temperature, initial $\mathrm{pH}$, fermentation time, rotational speed, and substrate concentration had a significant effect on bioconversion yield $(P<0.01)$. The saccharification and ethanol production of cassava 
stem was the synergism result of microorganism growth and the effect of enzyme, so the variation of $\mathrm{pH}$, temperature, and rotational speed will significantly affect the bioconversion yield. The suitable $\mathrm{pH}$ and temperature for microorganism growth and for the enzyme activity is different. Most of the fungal and yeast growth and their metabolites are suitable for the $\mathrm{pH}$ range of 4 to 6 . In general, the suitable $\mathrm{pH}$ for enzyme activity produced by A. fumigatus is 5 to 6 . Fermentation time showed a positive effect on the bioconversion yield, which means that the bioconversion yield will increase as the fermentation time increases within the experimental range. It is known that increasing the substrate concentration will enhance the overall bioconversion yield from cellulose (Tanaka et al. 2019). In the current work, a higher bioconversion yield with higher substrate concentration was obtained. This was similar to some of the results of previous works (Ang 2013), where the enzyme concentration in fermentation broth of A. fumigatus was directly affected by the substrate concentration. However, some other factors, such as physical properties and cellulose microstructure, that were not discussed in this experiment may also affect the bioconversion yield.

The conventional technique for the optimization of a multifactorial system is to deal with one factor at a time. However, this type of method is time-consuming and also does not reveal the alternative effects between components. In general, experimental results were enhanced by the optimization of the RSM more than the conventional optimization methods (Kamalini et al. 2018).

Figure 3 and figure 4 showed the response surface plots (Contour and 3D) of the experiment.
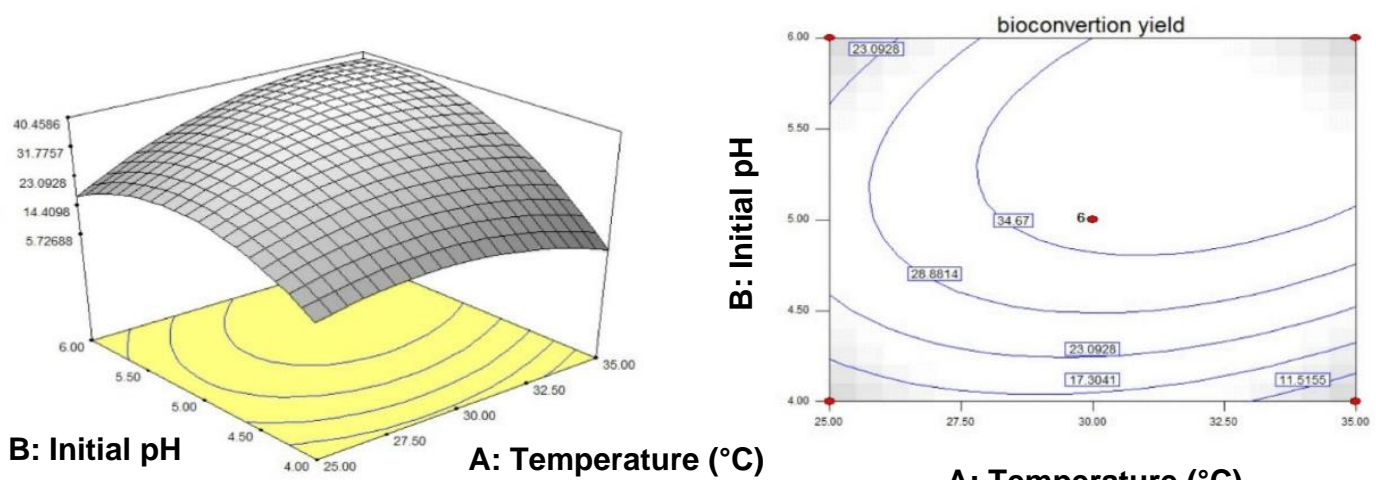

A: Temperature $\left({ }^{\circ} \mathrm{C}\right)$
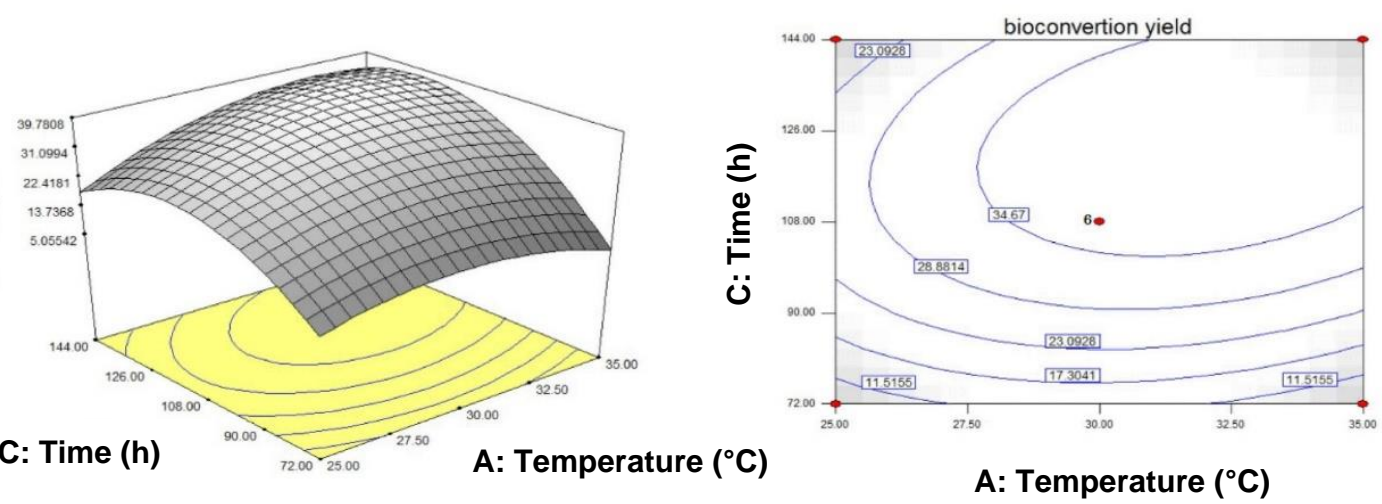

Fig. 3. Response surface plots (Contour and 3D) showing the interactive effects of temperature $\left({ }^{\circ} \mathrm{C}\right)$ and initial $\mathrm{pH}(\mathrm{AB})$ as well as temperature $\left({ }^{\circ} \mathrm{C}\right)$ and time $(\mathrm{h})(\mathrm{AC})$ on the Bioconversion yield 

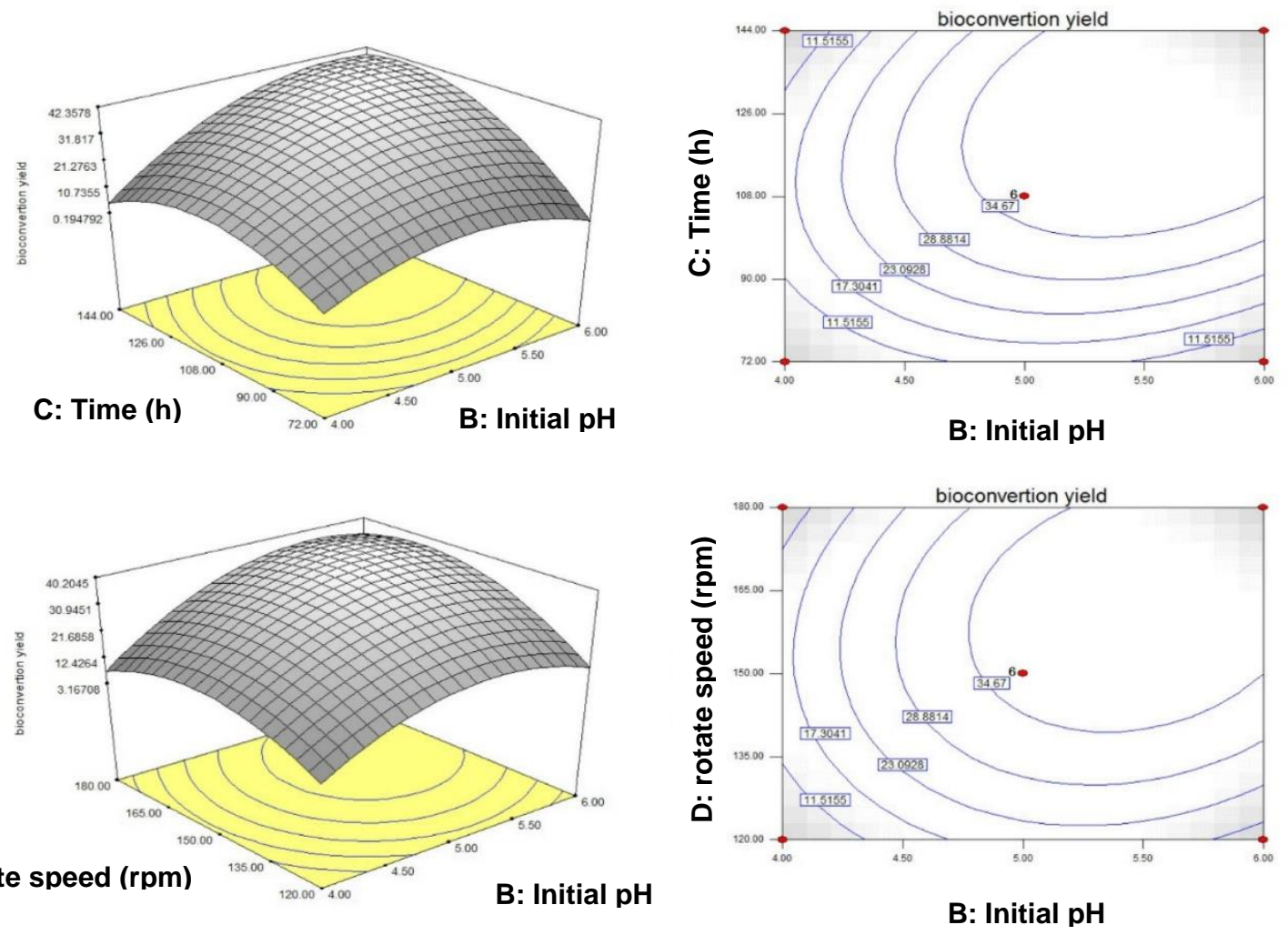

Fig. 4. Response surface plots (Contour and $3 \mathrm{D}$ ) showing the interactive effects of initial $\mathrm{pH}$ and time (h) (BC) as well as initial $\mathrm{pH}$ and rotate speed (rpm) (BD) on the Bioconversion yield

\section{Discussion}

Cassava stems are principally composed of cellulose, hemicellulose, and lignin. Many studies have shown that the lignin-hemicellulose matrix surrounding the cellulosic fraction will act as a physical barrier preventing the access of cellulase on the cellulose surface and thereby affecting the efficiency of lignocellulosic conversion (Alvira et al. 2010; Hsu et al. 2010). So the pretreatment is necessary to alter the physical and chemical properties, thereby enhancing enzymatic hydrolysis.

Various researchers have reported different pretreatment methods that can enhance the bioethanol production (Alvira et al. 2010; Nanssou et al. 2016). Among these methods, alkaline pretreatment was shown to be more effective and advantageous since it use lowcost chemicals and operate at lower temperatures (Balat 2011). However, this method usually takes a long time. Microwave and ultrasonic treatments have been studied as assistants to conventional pretreatment methods (Aguilar-Reynosa et al. 2017; Moodley and Kana 2017). Kamalini et al. (2018) investigated the application of response surface methodology on the effect of alkaline $\mathrm{NaOH}$ pretreatment on cassava stem powder under microwave conditions. The maximum reducing sugar of $41 \pm 2 \mathrm{mg} / \mathrm{L}$ was obtained under the optimal process parameters. The relatively high result of $6.6 \pm 2 \mathrm{~g} / \mathrm{L}$ of reducing sugar was obtained during the fermentation process in the present work. 


\section{CONCLUSIONS}

1. Bioconversion of cassava stem to ethanol using Aspergillus fumigatus and Saccharomyces cerevisiae in one process is feasible. The bioconversion yield of 70 $\mathrm{mg} / \mathrm{g}$ can be obtained at a fermentation temperature of $35{ }^{\circ} \mathrm{C}$, initial $\mathrm{pH} 5.5$, fermentation time $132 \mathrm{~h}$, rotational speed $155 \mathrm{rpm}$, and substrate concentration 4.6\%.

2. The pretreatment by microwave treatment combined with alkaline solution on cassava stem powder was more suitable for the saccharification and subsequent ethanol production.

3. The RSM was a good way to optimize the bioconversion process.

4. Aspergillus fumigatus is the suitable strain for the saccharification of cellulose due to its production capability of cellulase and hemicellulose.

\section{ACKNOWLEDGEMENTS}

The authors are grateful for the support of the Natural Science Foundation by the Science Technology Department of Zhejiang Province, China (Grant No. LY17C010001).

\section{REFERENCES CITED}

Aguilar-Reynosa, A., Romaní, A., Rodríguez-Jasso, R. M., Aguilar, C. N., Garrote, G., and Ruiz, H. A. (2017). "Microwave heating processing as alternative of pretreatment in second-generation biorefinery: An overview," Energy Conversion and Management. 136, 50-65. DOI:10.1016/j.enconman.2017.01.004

Alvira, P., Tomas-Pejo, E., Ballesteros, M., and Negro, M. J. (2010). "Pretreatment technologies for an efficient bioethanol production process based on enzymatic hydrolysis: A review," Bioresource Technology 101(13), 4851-4861.

DOI:10.1016/j.biortech.2009.11.093

Ang, S. K.., Shaza, E. M., Adibah, Y., Suraini, A. A., and Madihah, M. S. (2013). "Production of cellulases and xylanase by Aspergillus fumigatus SK1 using untreated oil palm trunk through solid state fermentation," Process Biochemistry 48(9), 12931302. DOI:10.1016/j.procbio.2013.06.019

Balat, M. (2011). "Production of bioethanol from lignocellulosic materials via the biochemical pathway: A review," Energy Conversion and Management 52, 858-875. DOI:10.1016/j.enconman.2010.08.013.

Germec, M., and Turhan, I. (2018). "Ethanol production from acid-pretreated and detoxified rice straw as sole renewable resource," Biomass Conversion and Biorefinery 8(3), 607-619. DOI: 10.1007/s13399-018-0310-1

Hsu, T. C., Guo, G. L., Chen, W. H., and Hwang, W. S. (2010). "Effect of dilute acid pretreatment of rice straw on structural properties and enzymatic hydrolysis," Bioresource Technology 101(13), 4907-4913. DOI:10.1016/j.biortech.2009.10.009

Intaramas, K., Jonglertjunya, W., Laosiripojana, N., and Sakdaronnarong, C. (2018). "Selective conversion of cassava mash to glucose using solid acid catalysts by 
sequential solid state mixed-milling reaction and thermo-hydrolysis," Energy 149, 837-847. DOI: 10.1016/j.energy.2018.02.073

Kamalini, A., Muthusamy, S., Ramapriya, R., Muthusamy, B., and Pugazhendhi, A. (2018). "Optimization of sugar recovery efficiency using microwave assisted alkaline pretreatment of cassava stem using response surface methodology and its structural characterization," Journal of Molecular Liquids 254, 55-63. DOI:

10.1016/j.molliq.2018.01.091

Kouteu Nanssou, P. A., Jiokap Nono, Y., and Kapseu, C. (2016). "Pretreatment of cassava stems and peelings by thermohydrolysis to enhance hydrolysis yield of cellulose in bioethanol production process," Renewable Energy 97, 252-265. DOI: 10.1016/j.renene.2016.05.050

Martín, C., Wei, M., Xiong, S., and Jönsson, L. J. (2017). "Enhancing saccharification of cassava stems by starch hydrolysis prior to pretreatment," Industrial Crops and Products 97, 21-31. DOI: 10.1016/j.indcrop.2016.11.067

Moodley, P., and Kana, E.G. (2017). "Development of a steam or microwave-assisted sequential salt-alkali pretreatment for lignocellulosic waste: Effect on delignification and enzymatic hydrolysis," Energy Conversion and Management 148, 801-808. DOI:10.1016/j.enconman.2017.06.056

Nanssou, P. A. K., Nono, Y. J., and Kapseu, C. (2016). "Pretreatment of cassava stems and peelings by thermohydrolysis to enhance hydrolysis yield of cellulose in bioethanol production process," Renewable Energy 972, 52-265.

DOI:10.1016/j.renene.2016.05.050

Niethammer, B., Wodarz, S., Betz, M., Haltenort, P., Oestreich, D., Hackbarth, K., Arnold U., Otto T., and Sauer J. (2018). "Alternative liquid fuels from renewable resources," Chemie Ingenieur Technik 90(1-2), 99-112. DOI:

10.1002/cite.201700117

Pattiya, A. (2011). "Bio-oil production via fast pyrolysis of biomass residues from cassava plants in a fluidised-bed reactor," Bioresource Technology 102(2), 19591967. DOI: 10.1016/j.biortech.2010.08.117

Pattiya, A., Sukkasi, S., and Goodwin, V. (2012). "Fast pyrolysis of sugarcane and cassava residues in a free-fall reactor," Energy 44(1), 1067-1077. DOI: 10.1016/j.energy.2012.04.035

Septia, E., Supriadi, Suwinarti, W., and Amirta, R. (2018). "Characterization and ethanol potential from giant cassava (Manihot esculenta) stem waste biomass," IOP Conference Series: Earth and Environmental Science 144, Article ID 012042. DOI: 10.1088/1755-1315/144/1/012042

Shen, Y., Yu, S., Ge, S., Chen, X., Ge, X., and Chen, M. (2017). "Hydrothermal carbonization of medical wastes and lignocellulosic biomass for solid fuel production from lab-scale to pilot-scale," Energy 118, 312-323. DOI:

10.1016/j.energy.2016.12.047

Singh, R. D., Banerjee, J., Sasmal, S., Muir, J., and Arora, A. (2018). "High xylan recovery using two stage alkali pre-treatment process from high lignin biomass and its valorisation to xylooligosaccharides of low degree of polymerisation," Bioresource Technology 256, 110-117. DOI: 10.1016/j.biortech.2018.02.009

Tanaka, K., Koyama, M., Pham, P. T., Rollon, A. P., Habaki, H., Egashira, R., and Nakasaki, K. (2019). "Production of high-concentration bioethanol from cassava stem by repeated hydrolysis and intermittent yeast inoculation," International Biodeterioration \& Biodegradation 138, 1-7. DOI: 10.1016/j.ibiod.2018.12.007 
Veiga, J. P. S., Valle, T. L., Feltran, J. C., and Bizzo, W. A. (2016). "Characterization and productivity of cassava waste and its use as an energy source," Renewable Energy 93, 691-699. DOI: 10.1016/j.renene.2016.02.078

Yang, Z., Qian, K., Zhang, X., Lei, H., Xin, C., Zhang, Y., Qian, M., and Villota, E. (2018). "Process design and economics for the conversion of lignocellulosic biomass into jet fuel range cycloalkanes," Energy 154, 289-297. DOI: 10.1016/j.energy.2018.04.126

Zhou, J.-Z., Feng, J.-X., Xu, Q., and Zhao, Y.-J. (2018). “A much cheaper method to separate ethanol after solid-state fermentation process in renewable energy production," Renewable Energy 123, 675-682. DOI: 10.1016/j.renene.2018.02.052

Zhu, S., Wu, Y., Yu, Z., Zhang, X., Wang, C., Yu, F., Jin, S., Zhao, Y., and Xue, Y. (2005). "Simultaneous saccharification and fermentation of microwave/alkali pretreated rice straw to ethanol," Biosystems Engineering 92(2), 229-235. DOI: 10.1016/j.biosystemseng.2005.06.01

Article submitted: April 17, 2019; Peer review completed: June 6, 2019; Revised version received and accepted: July 8, 2019; Published: July 10, 2019.

DOI: $10.15376 /$ biores.14.3.6895-6908 